\title{
Disability as a determinant of fatigue in MS patients
}

\author{
Incapacidade como determinante da fadiga em pacientes com EM \\ Fernanda M. TAVEIRA', Nayara F.T.BRAZ1,2, Elizabeth R. COMINI-FROTA', Antônio L. TEIXEIRA ${ }^{1,2}$, Renan B. DOMINGUES
}

\begin{abstract}
Fatigue is one of the most frequent and disabling symptoms in multiple sclerosis (MS). Central, psychological, and peripheral factors may contribute to the occurrence of fatigue. Objectives: The current study aimed to evaluate potential fatigue determinants in patients with relapsing-remitting MS with a low functional impairment. Methods: We compared inflammatory markers, respiratory pressures, disability, and quality of life in 39 relapsing-remitting MS patients with and without fatigue. Results: Patients with relapsing-remitting MS with fatigue had higher Expanded Disability Status Scale scores ( $p=0.002)$. We observed a significant association between the results of the Guy Neurological Disability Scale, the Functional Assessment of MS Quality of Life Rating Scale and the presence of fatigue ( $<$ 0.05). Conclusions: The degree of functional impairment is a determinant for the presence of fatigue in MS patients, but respiratory function and inflammatory markers are not.
\end{abstract}

Keywords: Multiple sclerosis; fatigue; inflammation.

\section{RESUMO}

A fadiga é um dos sintomas mais frequentes e incapacitantes na esclerose múltipla (EM). Fatores centrais, psicológicos e periféricos podem contribuir para a ocorrência de fadiga. Objetivos: 0 presente estudo teve como objetivo avaliar potenciais determinantes de fadiga em pacientes com EM remitente-recorrente (EMRR) com baixo nível de incapacidade funcional. Métodos: Foram comparados marcadores inflamatórios, pressões respiratórias, incapacidade e qualidade de vida em 39 pacientes com EMRR com e sem fadiga. Resultados: Pacientes com EMRR com fadiga apresentaram maior Escala de Incapacidade Funcional Expandida ( $p=0,002)$. Observamos uma associação significativa entre os resultados da Escala de Incapacidade Neurológica de Guy e Escala de Avaliação da Qualidade de Vida Funcional com a presença de fadiga (valores de $\mathrm{p}<0,05$ ). Conclusão: 0 grau de comprometimento funcional, mas não a função respiratória e os marcadores inflamatórios, são determinantes para a presença de fadiga em pacientes com EM.

Palavras-chave: Esclerose múltipla; fadiga; inflamação.

Multiple sclerosis (MS) is a chronic demyelinating and inflammatory disease of the central nervous system. Fatigue is one of the most frequent and disabling symptoms in patients with MS, affecting nearly $75-90 \%$ of patients $^{1}$. Fatigue in MS is a multifactorial and complex symptom whose pathophysiology is not yet fully understood $^{2}$. Dysregulation of the immune system, neurophysiological, and neuroendocrine dysfunctions, as well as other factors such as lack of physical conditioning, sleep disturbances, pain, and drug side effects, have been proposed as potential determinants of fatigue ${ }^{3}$. The role of inflammation or immune dysfunction in fatigue is still debatable. Theoretically, altered cytokine concentrations in MS could contribute to the occurrence of fatigue 4 . It has been suggested that some pro-inflammatory cytokines, such as IL-6 and TNF- $\alpha$, may play a prominent role in the development of fatigue ${ }^{5,6}$.

A role of respiratory impairment in fatigue development in MS has also been proposed. A significant inverse correlation between fatigue severity and respiratory muscle strength and endurance suggests that respiratory muscle weakness may contribute to fatigue in MS patients ${ }^{7}$. Once present, fatigue has been associated with reduced perception of quality of life $^{1,8}$, limited physical activity ${ }^{9,10}$, depression and anxiety ${ }^{11,12}$ among MS patients. Most studies have evaluated fatigue in patients with significant functional impairment, but only a

\footnotetext{
'Universidade Federal de Minas Gerais, Programa de Pós-graduação em Neurociências, Belo Horizonte MG, Brasil;

${ }^{2}$ Universidade Federal de Minas Gerais, Escola de Medicina, Laboratório Interdisciplinar de Investigação Médica, Belo Horizonte MG, Brasil.

Fernanda Machado Taveira (iD) http://orcid.org/0000-0002-2917-9230
}

Correspondence:Fernanda Machado Taveira; Rua José Teixeira, 200 / apt. 1002 - Praia do Canto; 29055-310 Vitória ES, Brasil. E-mail:fernandamtaveira@gmail.com Support: This work was partly funded by Fapemig and CNPq, Brazilian Government funding agencies.

Conflict of interest: There is no conflict of interest to declare.

Received 10 September 2018; Received in final form 26 December 2018; Accepted 09 January 2019. 
few studies have evaluated this symptom in patients with low functional impairment scores ${ }^{1,7,12}$.

In the present study, we evaluated potential fatigue determinants in patients with relapsing-remitting MS with a low level of functional impairment.

\section{METHODS}

\section{Participants}

Thirty-nine patients with relapsing-remitting MS according to the criteria established by the International Panel for the Diagnosis of Multiple Sclerosis ${ }^{13}$ were included in this study. All patients were using disease-modifying drugs and were receiving regular neurological follow-up. All patients had low level of disability (Expanded Disability Status Scale [EDSS] $\leq 4)$. Patients with other neurological or pulmonary diseases, temporomandibular dysfunction, altered Mini Mental State Examination (scores < 25), as well as patients already undergoing respiratory physiotherapy or who had had a relapse in the last three months were not included.

All participants were over 18 years old, and signed a written informed consent.

Body mass index, inflammatory markers (TNF and IL-6), maximal inspiratory pressure, maximal expiratory pressure and peak expiratory flow were determined. The EDSS ${ }^{14}$, Guy Neurological Disability Scale (GNDS) $)^{15}$ and the Functional Assessment of Multiple Sclerosis (FAMS) quality of life scale ${ }^{16}$ were applied to all patients. The Modified Fatigue Impact Scale ${ }^{17}$ scale was used to assess fatigue. The patients were considered to have clinically significant fatigue when the Modified Fatigue Impact Scale score was equal to or greater than $38^{12}$. Based on the fatigue score, the patients were divided according to the presence or absence of fatigue, to analyze the other variables.

The study was approved by the local ethics committee of the Federal University of Minas Gerais, Brazil.

\section{Inflammatory markers determination}

Ten milliliters of peripheral venous blood were collected in BD-Vacutainer tubes containing sodium heparin, from the 39 patients. After collection, the samples were submitted to centrifugation at 3,000 g for 10 minutes. Plasma was collected and stored in a freezer at $-80^{\circ} \mathrm{C}$. All the analyses were carried out at the Interdisciplinary Laboratory of Medical Investigation of the Federal University of Minas Gerais.

A cytometric bead array was performed to determination of TNF and IL-6 cytokines, following the instructions from the manufacturer (Becton \& Dickinson, San Jose, CA, USA). The results were expressed as $\mathrm{pg} / \mathrm{mg}$ of total protein.

\section{Manovacuometry and peak flow}

Measurements of respiratory pressures were performed using a manovacuometer (model M120; Commercial Medical, São Paulo, Brazil) with a variation from $-120 \mathrm{cmH}_{2} \mathrm{O}$ (maximal inspiratory pressure) to $+120 \mathrm{cmH}_{2} \mathrm{O}$ (maximal expiratory pressure). Peak expiratory flow was determined according to the manufacturer's recommendations (Asses model, full range 60-880 L/min, Respironics New Jersey, Inc., USA). All procedures were performed three times and the largest measure obtained was selected.

\section{Statistical analysis}

Statistical analysis was performed with SPSS software. The 95\% confidence interval (CI) was adopted, and the level of significance was set at $\mathrm{p}<0.05$. The Shapiro-Wilk test was used to assess normality of data.

In a univariate analysis, we evaluated the factors associated with the presence of fatigue among MS cases. The Chisquare test or Fisher's exact test were used to compare the categorical variables. In the comparison of numerical variables, the nonparametric Mann-Whitney test was used for the variables with asymmetric distribution and the Student's t-test for those with normal distribution.

In the multivariate analysis, the binary logistic regression model was used. For input of predictor variables in the model, a p-value of less than 0.20 was considered in the univariate analysis. The forward criterion was used to enter the variables in the model and, for the permanence of the variables in the final model, a level of $5 \%$ of significance was adopted.

After adjustment of the final model, the odds ratio adjusted with the respective $95 \%$ CI was evaluated.

\section{RESULTS}

The demographic data analyzed were not significantly different between patients with and without fatigue. The EDSS, GNDS, and FAMS scores were higher among patients with fatigue (Table 1).

No significant difference in the evaluated respiratory parameters and inflammatory markers was found between patients with and without fatigue (Tables 2 and 3 ).

Age, EDSS score, smoking, maximal expiratory pressure, peak expiratory flow, GNDS, and FAMS scores were evaluated by multivariate analysis considering the presence of fatigue as the dependent variable (Table 4).

The only variable that showed a significant association with the presence of fatigue was the GNDS score (odds ratio $1.62,95 \%$ CI 1.20-2.18). The binary logistic regression model indicated that with the increase of one unit in the total GNDS score, there is a 1.62-fold increase in the chance of presenting with fatigue ( $95 \% \mathrm{CI}=1.20-2.18)$ (Table 5).

\section{DISCUSSION}

In the last decades, several instruments for evaluating clinical severity and functional deficits in MS have been translated, 
Table 1. Demographic and clinical characteristics associated with the presence of fatigue among MS patients.

\begin{tabular}{|c|c|c|c|}
\hline \multirow{2}{*}{ Variable } & \multicolumn{2}{|c|}{ Presence of Fatigue } & \multirow{2}{*}{$\mathrm{p}$-value } \\
\hline & No $(n=20)$ & Yes $(n=19)$ & \\
\hline Age & & & $0.181 * \star$ \\
\hline Mean \pm standard deviation & $35.8 \pm 7.2$ & $42.6 \pm 13.3$ & \\
\hline Median (minimum - maximum) & $35(20-53)$ & $38(25-64)$ & \\
\hline Sex & & & $1.000 *$ \\
\hline Women & $17(85.0 \%)$ & $16(84.2 \%)$ & \\
\hline Men & $3(15.0 \%)$ & $3(15.8 \%)$ & \\
\hline Expanded Disability Status Scale & & & $0.002 * \star$ \\
\hline Mean \pm standard deviation & $2.0 \pm 0.8$ & $2.8 \pm 0.7$ & \\
\hline Median (minimum - maximum) & $1.8(1.0-4.0)$ & $3.0(1.5-4.0)$ & \\
\hline Diagnosis (months prior) & & & $0.407 * \star$ \\
\hline Mean \pm standard deviation & $103.3 \pm 71.2$ & $84.7 \pm 68.1$ & \\
\hline Median (minimum - maximum) & $102(12-264)$ & $60(1-288)$ & \\
\hline Drug treatment & & & $0.182^{\star}$ \\
\hline Yes & $19(95.0 \%)$ & $15(78.9 \%)$ & \\
\hline No & $1(5.0 \%)$ & $4(21.1 \%)$ & \\
\hline Smoking & & & $0.182^{\star}$ \\
\hline Ex-smoker & $1(5.0 \%)$ & $4(21.1 \%)$ & \\
\hline Non-smoker & $19(95.0 \%)$ & $15(78.9 \%)$ & \\
\hline Body Mass Index & & & $0.241 * * *$ \\
\hline Mean \pm standard deviation & $25.4 \pm 4.8$ & $23.8 \pm 3.3$ & \\
\hline Median (minimum - maximum) & $25.6(17.2-35.5)$ & $23.5(18.1-30.1)$ & \\
\hline Last relapse (months prior) & & & $0.463^{\star *}$ \\
\hline Mean \pm standard deviation & $31.6 \pm 16.4$ & $33.4 \pm 33.0$ & \\
\hline Median (minimum - maximum) & $31.8(5-60)$ & $22.8(3-132)$ & \\
\hline
\end{tabular}

*Fisher's exact test; ${ }^{\star \star M a n n-W h i t n e y ~ t e s t ; ~}{ }^{\star \star \star S t u d e n t ' s ~ t-t e s t . ~}$

Table 2. Results of maximal inspiratory pressure, maximum expiratory pressure and peak expiratory flow associated with the presence of fatigue among MS patients.

\begin{tabular}{|c|c|c|c|}
\hline \multirow{2}{*}{ Variable } & \multicolumn{2}{|c|}{ Presence of Fatigue } & \multirow{2}{*}{$p$-value } \\
\hline & No $(n=20)$ & Yes $(n=19)$ & \\
\hline Maximal inspiratory pressure & & & $0.253^{*}$ \\
\hline Mean \pm standard deviation & $93.6 \pm 18.3$ & $87.7 \pm 15.8$ & \\
\hline Median (minimum-maximum) & $100(56-120)$ & $88(60-116)$ & \\
\hline Maximum expiratory pressure & & & $0.058^{*}$ \\
\hline Mean \pm standard deviation & $94.8 \pm 14.4$ & $85.3 \pm 18.9$ & \\
\hline Median (minimum-maximum) & $96(60-120)$ & $80(48-116)$ & \\
\hline Peak expiratory fflow & & & $0.084^{\star *}$ \\
\hline Mean \pm standard deviation & $442.8 \pm 126.3$ & $382.6 \pm 78.0$ & \\
\hline Median (minimum-maximum) & $445(250-730)$ & $360(260-550)$ & \\
\hline
\end{tabular}

*Mann-Whitney test; **Student's t-test.

validated and standardized into the Portuguese language. Such instruments are increasingly being used as parameters to evaluate the efficacy of therapeutic interventions.

The most popular and widely-used instrument is the EDSS. The EDSS is a clinician-administered assessment scale evaluating the functional systems of the central nervous system. It consists of an ordinal rating system ranging from 0 (normal neurological status) to 10 (death due to MS) in 0.5 increment intervals (when reaching EDSS 1). The lower scale values of the EDSS measure impairments based on the 
Table 3. Association between inflammatory biomarkers and the presence of fatigue among the patients with MS.

\begin{tabular}{|c|c|c|c|}
\hline \multirow{2}{*}{ Variable } & \multicolumn{2}{|c|}{ Presence of Fatigue } & \multirow{2}{*}{$\mathrm{p}$-value } \\
\hline & No $(n=20)$ & Yes $(n=19)$ & \\
\hline TNF (pg/ml) & & & $0.866^{*}$ \\
\hline Mean \pm standard deviation & $10.6 \pm 18.5$ & $9.3 \pm 28.4$ & \\
\hline Median (minimum-maximum) & $1.6(0.9-71.0)$ & $1.7(0.7-125.3)$ & \\
\hline IL-6 (pg/ml) & & & $0.285^{\star}$ \\
\hline Mean \pm standard deviation & $9.5 \pm 15.4$ & $9.7 \pm 22.2$ & \\
\hline Median (minimum-maximum) & $2.0(1.3-62.2)$ & $3.2(1.5-97.9)$ & \\
\hline
\end{tabular}

Table 4. Other scales associated with the presence of fatigue among the cases of MS.

\begin{tabular}{|c|c|c|c|}
\hline \multirow{2}{*}{ Variable } & \multicolumn{2}{|c|}{ Presence of Fatigue } & \multirow{2}{*}{$\mathrm{p}$-value } \\
\hline & No $(n=20)$ & Yes $(n=19)$ & \\
\hline Guy neurological disability scale & & & $<0.001^{* *}$ \\
\hline Mean \pm standard deviation & $4.9 \pm 3.7$ & $14.8 \pm 5.9$ & \\
\hline Median (minimum-maximum) & $4.5(0-14)$ & $14(3-29)$ & \\
\hline Functional assessment of MS quality of life rating scale & & & $<0.001 * \star$ \\
\hline Mean \pm standard deviation & $138.8 \pm 33.9$ & $109.2 \pm 22.5$ & \\
\hline Median (minimum-maximum) & $148(13-169)$ & $108(59-148)$ & \\
\hline
\end{tabular}

Table 5. Multivariate analysis using the binary logistic regression model evaluating the factors associated with the presence of fatigue $(n=39)$.

\begin{tabular}{lccc} 
Variable & p-value & $\begin{array}{l}\text { Odds } \\
\text { Ratio }\end{array}$ & $95 \% \mathrm{Cl}$ \\
\hline $\begin{array}{l}\text { Guy neurological disability } \\
\text { scale }\end{array}$ & 0.001 & 1.62 & {$[1.20-2.18]$} \\
\hline
\end{tabular}

*Value-p Hosmer \& Lemeshow test (model fit) $=0.229$

neurological examination, while the upper range of the scale (EDSS > 6) measures the handicaps of patients with MS. The determination of EDSS 4-6 is heavily dependent on aspects of walking ability ${ }^{14}$.

The GNDS has subsequently been introduced as a new measure of disability, based mainly on the patient's self-report. It is patient-orientated, multidimensional, and not biased towards any particular disability. The GNDS was devised to be a simple, user-friendly clinical disability scale capable of assessing the whole range of disabilities (cognition, mood, vision, communication, deglutition, upper and lower limbs, bladder and bowel function, sexual function and fatigue) that may be encountered in the course of $\mathrm{MS}^{15}$.

Our study showed an association between disability (EDSS and GNDS) and the frequency of fatigue in relapsing-remitting MS patients. Similar findings have been reported in MS patients in different stages of the disease (EDSS 2.5-7) ${ }^{18,19,20}$. Although the GNDS is considered a valid tool for the evaluation of MS patients, we did not find any study that had used this as a scale of disability assessment and its relationship with the frequency of fatigue in this population. Since fatigue is one of the subitems analyzed in this scale, we question whether this fact would influence the result of higher values of GNDS in patients with fatigue. However, the GDNS is a generic instrument and is not considered an instrument for the direct evaluation of fatigue. Fatigue is a particularly subjective and heterogeneous complaint that varies among individuals in frequency, severity, means of installation, and psychosocial conditions. All these aspects should be taken into account in the evaluation, as well as in the Modified Fatigue Impact Scale.

Our findings suggest that the association between the presence of fatigue and disability, measured by any valid tool, may occur even in patients with low disability scores.

Other studies have pointed to fatigue and disease progression ${ }^{21,22}$ as determinants in reducing the quality of life in this population. Quality of life measures are alternative indicators of the impact of the disease, particularly relevant in chronic conditions ${ }^{22}$.

A significant relationship between the lower quality of life indices (FAMS) and the presence of fatigue was also noted. For about $40 \%$ of the population with MS, fatigue is the most disabling symptom of the disease, affecting quality of life ${ }^{23}$.

We found no significant association of any of the respiratory parameters analyzed with the presence of fatigue. Some studies have suggested that respiratory muscle weakness may be one of the determinants of fatigue in MS patients ${ }^{24,25}$. Muscle weakness can occur in both the inspiratory and expiratory musculature muscles. It has been proposed that in 
MS the expiratory muscles (abdominal and internal intercostal muscle) are affected prior to the inspiratory muscles (diaphragm and external intercostal muscle) ${ }^{25}$. Involvement of respiratory muscles may occur in early stages of MS and respiratory function should be assessed in patients with apparently normal function and without respiratory complaints $^{7,26}$. A possible relationship of fatigue with respiratory parameters could be explained by the fact that respiratory muscle weakness requires an increased neural stimulation to support alveolar ventilation and adequate gas exchange, generating fatigue ${ }^{27}$. Considering that fatigue is multifactorial and that it is influenced by the stage of the disease, it is possible that the inclusion of only patients with a low degree of functional disability has precluded the demonstration of other correlations.

No association between the levels of pro-inflammatory cytokines (TNF- $\alpha$ and IL-6) and fatigue was found. Previous studies have shown conflicting data in this regard $^{6}$. Some studies indicated that TNF- $\alpha$ levels are increased in MS patients compared with healthy controls and that higher levels of TNF- $\alpha$ can be correlated with the risk of progression of disability ${ }^{28,29}$. Some studies found associations between cytokine levels and fatigue ${ }^{30,31}$ while others did not ${ }^{32,33}$. For instance, one study reported an association between IL-6 and fatigue, suggesting this proinflammatory cytokine may play a role in the pathophysiology of fatigue in $\mathrm{MS}^{34}$. There are possible reasons for the conflicting results in the literature, including heterogeneity of the MS sample regarding stage of the disease and immune-based treatment. Among the studies evaluating this relationship, our study was the only one that included only patients with relapsing-remitting disease, with a low degree of functional disability, and with all the patients using immunomodulatory agents. These population differences may explain the discrepant findings. Rigorous selection criteria and sample uniformity allow these results to be extrapolated to similar populations. Future studies evaluating neuroimaging and a broader panel of immunological biomarkers may further contribute to the understanding of fatigue in MS.

In conclusion, disability determined the occurrence of fatigue in MS patients. Neither respiratory function nor inflammatory blood markers were able to predict fatigue in MS patients with a low degree of disability.

\section{References}

1. Brañas P, Jordan R, Fry-Smith A, Burls A, Hyde C. Treatments for fatigue in multiple sclerosis: a rapid and systematic review. Health Technol Assess. 2000;4(27):1-61.

2. Rudroff T, Kindred JH, Ketelhut NB. Fatigue in Multiple Sclerosis: Misconceptions and Future Research Directions. Front Neurol. 2016 Aug;7:122. https://doi.org/10.3389/fneur.2016.00122

3. Franceschini M, Rampello A, Bovolenta F, Aiello M, Tzani P, Chetta A. Cost of walking, exertional dyspnoea and fatigue in individuals with multiple sclerosis not requiring assistive devices. J Rehabil Med. 2010 Sep;42(8):719-23. https://doi.org/10.2340/16501977-0600

4. Patejdl R, Penner IK, Noack TK, Zettl UK. Multiple sclerosis and fatigue: A review on the contribution of inflammation and immune-mediated neurodegeneration. Autoimmun Rev. 2016 Mar;15(3):210-20. https://doi.org/10.1016/j.autrev.2015.11.005

5. Roerink ME, Schaaf ME, Dinarello CA, Knoop H, Meer JW. Interleukin-1 as a mediator of fatigue in disease: a narrative review. J Neuroinflammation 2017;21;14(1):16. https://doi.org/10.1186/s12974-017-0796-7

6. Yamato M, Tamura Y, Eguchi A, Kume S, Miyashige Y, Nakano M, et al. Brain interleukin-1 $\beta$ and the intrinsic receptor antagonist control peripheral Toll-like receptor 3-mediated suppression of spontaneous activity in rats. PLoS One. 2014 Mar;9(3):e90950. https://doi.org/10.1371/journal.pone.0090950

7. Koseoglu BF, Gokkaya NK, Ergun U, Inan L, Yesiltepe E. Cardiopulmonary and metabolic functions, aerobic capacity, fatigue and quality of life in patients with multiple sclerosis. Acta Neurol Scand. 2006 Oct;114(4):261-7. https://doi.org/10.1111/j.1600-0404.2006.00598.x

8. Janardhan V, Bakshi R. Quality of life in patients with multiple sclerosis: the impact of fatigue and depression. J Neurol Sci. 2002 Dec;205(1):51-8. https://doi.org/10.1016/S0022-510X(02)00312-X

9. Motl RW, McAuley E. Symptom cluster as a predictor of physical activity in multiple sclerosis: preliminary
evidence.J Pain Symptom Manage. 2009 Aug;38(2):270-80. https://doi.org/10.1016/j.jpainsymman.2008.08.004

10. Motl RW, McAuley E, Wynn D, Suh Y, Weikert M. Effects of change in fatigue and depression on physical activity over time in relapsing-remitting multiple sclerosis. Psychol Health Med. 2011 Jan;16(1):1-11. https://doi.org/10.1080/13548506.2010.521569

11. Putzki N, Katsarava Z, Vago S, Diener HC, Limmroth V. Prevalence and severity of multiple-sclerosis-associated fatigue in treated and untreated patients. Eur Neurol. 2008;59(3-4):136-42. https://doi.org/10.1159/000111876

12. Téllez N, Río J, Tintoré M, Nos C, Galán I, Montalban X. Does the Modified Fatigue Impact Scale offer a more comprehensive assessment of fatigue in MS? Mult Scler. 2005 Apr;11(2):198-202. https://doi.org/10.1191/1352458505ms11480a

13. Polman CH, Reingold SC, Banwell B, Clanet M, Cohen JA, Filippi $\mathrm{M}$, et al. Diagnostic criteria for multiple sclerosis: 2010 revisions to the McDonald criteria. Ann Neurol. 2011 Feb;69(2):292-302. https://doi.org/10.1002/ana.22366

14. Kurtzke JF. Rating neurologic impairment in multiple sclerosis: an expanded disability status scale (EDSS). Neurology. 1983 Nov;33(11):1444-52. https://doi.org/10.1212/WNL.33.11.1444

15. Sharrack B, Hughes RA. The Guy's Neurological Disability Scale (GNDS): a new disability measure for multiple sclerosis. Mult Scler. 1999 Aug;5(4):223-33. https://doi.org/10.1177/135245859900500406

16. Mendes MF, Balsimelli S, Stangehaus G, Tilbery CP. [Validation of the functional assessment of multiple sclerosis quality of life instrument in a Portuguese language]. Arq Neuropsiquiatr. 2004 Mar;62(1):108-13. Portuguese. https://doi.org/10.1590/S0004-282X2004000100019

17. Pavan K, Schmidt K, Marangoni B, Mendes MF, Tilbery CP, Lianza S. [Multiple sclerosis: cross-cultural adaptation and validation of the modified fatigue impact scale]. Arq Neuropsiquiatr. 2007 Sep;65(3A):669-73. Portuguese. https://doi.org/10.1590/S0004-282X2007000400024 
18. Braga DM, Prado GF, Bichueti DB, Oliveira EM. Positive correlation between functional disability, excessive daytime sleepiness, and fatigue in relapsing-remitting multiple sclerosis. Arq Neuropsiquiatr. 2016 Jun;74(6):433-8. https://doi.org/10.1590/0004-282×20160069

19. Šabanagić-Hajrić S, Suljić E, Kučukalić A. Fatigue during multiple sclerosis relapse and its relationship to depression and neurological disability. Psychiatr Danub. 2015 Dec;27(4):406-12.

20. Tabrizi FM, Radfar M. Fatigue, sleep quality, and disability in relation to quality of life in multiple sclerosis. Int J MS Care. 2015 Nov-Dec;17(6):268-74. https://doi.org/10.7224/1537-2073.2014-046

21. Amato MP, Ponziani G, Rossi F, Liedl CL, Stefanile C, Rossi L. Quality of life in multiple sclerosis: the impact of depression, fatigue and disability. Mult Scler. 2001 Oct;7(5):340-4. https://doi.org/10.1177/135245850100700511

22. Lobentanz IS, Asenbaum S, Vass K, Sauter C, Klösch G, Kollegger $\mathrm{H}$, et al. Factors influencing quality of life in multiple sclerosis patients: disability, depressive mood, fatigue and sleep quality. Acta Neurol Scand. 2004 Jul;110(1):6-13. https://doi.org/10.1111/j.1600-0404.2004.00257.x

23. Greim B, Benecke R, Zettl UK. Qualitative and quantitative assessment of fatigue in multiple sclerosis (MS). J Neurol. 2007 May;254(S2 Suppl 2):I158-64. https://doi.org/10.1007/s00415-007-2014-5

24. Ray AD, Mahoney MC, Fisher NM. Measures of respiratory function correlate with fatigue in ambulatory persons with multiple sclerosis. Disabil Rehabil. 2015 May;1(26):1-6. https://doi.org/10.3109/09638288.2015.1031286

25. Gosselink R, Kovacs L, Decramer M. Respiratory muscle involvement in multiple sclerosis. Eur Respir J. 1999 Feb;13(2):449-54. https://doi.org/10.1183/09031936.99.13244999

26. Krupp LB, LaRocca NG, Muir-Nash J, Steinberg AD. The fatigue severity scale. Application to patients with multiple sclerosis and systemic lupus erythematosus. Arch Neurol. 1989 Oct;46(10):1121-3. https://doi.org/10.1001/archneur.1989.00520460115022

Tantucci C, Massucci M, Piperno R, Betti L, Grassi V, Sorbini CA. Control of breathing and respiratory muscle strength in patients with multiple sclerosis. Chest. 1994 Apr;105(4):1163-70. https://doi.org/10.1378/chest.105.4.1163

28. Graber JJ, Dhib-Jalbut S. Biomarkers of disease activity in multiple sclerosis. J Neurol Sci 2011;15:305(1-2):1-10. https://doi.org/10.1016/j.jns.2011.03.026

29. Sharief MK, Hentges R. Association between tumor necrosis factor-alpha and disease progression in patients with multiple sclerosis. N Engl J Med 1991;15;325(7):467-72. https://doi.org/10.1056/NEJM199108153250704

30. Flachenecker P, Bihler I, Weber F, Gottschalk M, Toyka KV, Rieckmann P. Cytokine mRNA expression in patients with multiple sclerosis and fatigue. Mult Scler. 2004 Apr;10(2):165-9. https://doi.org/10.1191/1352458504ms991oa

31. Heesen C, Nawrath L, Reich C, Bauer N, Schulz KH, Gold SM. Fatigue in multiple sclerosis: an example of cytokine mediated sickness behaviour? J Neurol Neurosurg Psychiatry. 2006 Jan;77(1):34-9. https://doi.org/10.1136/jnnp.2005.065805

32. Giovannoni G, Thompson AJ, Miller DH, Thompson EJ. Fatigue is not associated with raised inflammatory markers in multiple sclerosis. Neurology. 2001 Aug;57(4):676-81. https://doi.org/10.1212/WNL.57.4.676

33. Heesen C, Koehler G, Gross R, Tessmer W, Schulz KH, Gold $\mathrm{SM}$. Altered cytokine responses to cognitive stress in multiple sclerosis patients with fatigue. Mult Scler. 2005 Feb;11(1):51-7. https://doi.org/10.1191/1352458505ms1129oa

34. Malekzadeh A, Van de Geer-Peeters W, De Groot V, Teunissen CE, Beckerman H; TREFAMS-ACE Study Group. Fatigue in patients with multiple sclerosis: is it related to pro- and anti-inflammatory cytokines? Dis Markers. 2015;2015:758314. https://doi.org/10.1155/2015/758314 